\title{
AT THE INTERSECTION OF JURISDICTION AND CHOICE OF LAW
}

Trial by closed circuit television is easily visualized-the plaintiff in Oregon, the defendant in Florida, the presiding judge in Georgia. ${ }^{1}$ Picture telepliones are already available, ${ }^{2}$ conference calls adapted to courtrooin use will be economically feasible soon, perhaps within the decade. $^{3}$

In many cases, trial-by-picturephone can enlaance convenience to the litigants and their witnesses while satisfying judicial fairness standards. Although our rules of evidence ${ }^{4}$ and procedure will require

1. A case that might well merit such procedural treatment was before the Oregon supreme court in State ex rel. White Lumber Co. v. Sulmonetti, 252 Ore. 121, 448 P.2d 571 (1968). A contract concluded by telephone between Florida and Oregon lumber wholesalers led to a dispute over the quality of goods shipped to Georgia from Oregon at the request of the Florida purchaser. The Oregon wholesaler brought suit in Oregon and the Oregon supreme court upheld service of process under the provisions of the Oregon long-arm statute, which authorizes its courts to take jurisdiction over any dispute involving "the transaction of any business within this state . . .." OrE. REv. STAT. \$ 14.035(1) (a) (1963). The majority opinion displays contemporary concern with itemization of defendant-forum contacts, concluding that service of process is permissible when the dispute arises from actions of a foreign corporation that purposefully produce economic consequences in Oregon. 252 Ore. at 126-27, 448 P.2d at 573-74. In a dissent that has received considerable attention, Chief Justice O'Connell proposes the replacement of due process jurisdictional tests with new standards to be developed under the full faith and credit clause. 252 Ore. at 130, 140 n.21, 448 P.2d at 575, 580 n.21, discussed in Ehrenzweig, From State Jurisdiction to Intersiate Venue, 50 ORE. L. REv. 103 (1971); Scoles, Oregon Conflicts, 49 ORE. L. REv. 273, 275-80 (1970); Comment, Long-Arm and Quasi in Rem Jurisdiction and the Fundamental Test of Fairness, 69 Mrcr. L. REv. 300, 303-05 (1970); Note, The Oregon "Long-Arm" Statute, 5 WILLAMETTE L.J. 589, 596-600 (1969). Chief Justice O'Connell incorporates two features in his proposal that distinguish his approach from that set forth in this Comment. First, he places greater reliance on Professor Rheinstein's jus gentium approach to the full faith and credit clause. 252 Ore. at 132, 448 P.2d at 576. Compare Rheinstein, The Constitutional Bases of Jurisdiction, 22 U. CHI. L. REv. 775, 802-12 (1955) with text accompanying notes 96-131 infra. Second, he indicates an apparently greater preference for jurisdictional rules that incorporate a basic defendant bias. Compare 252 Ore. at 137-39, 448 P.2d at 579-80 with text accompanymg notes 138-43 infra.

2. The state of the art is covered extensively in a symposium in $50 \mathrm{BELL}$ SYS. TECH. J. 219 (1971).

3. Telephone conversation with Conrad Pologe, American Telephone and Telegraph Company, New York City, Aug. 30, 1971.

4. Basic issues of evidence and the right of confrontation are deliberately excluded from this discussion. However, a few observations are appropriate. Although the sixth amendment, by its terms, does not apply to civil cases, hearsay rules provide similar protection and the considerations in either case are much the same. Does the 
updating, the greatest impact will be in the areas of jurisdiction and choice of law. Given no single physical forum, jurisdictional rules as currently formulated and applied to cases involving multistate eleinents will be largely irrelevant. Assuming continuing differences in state laws, choice of law directives will be required. ${ }^{5}$ And their availability in picturephone cases is certain to affect the jurisdictional patterns of more conventional litigation.

Even apart from future doctrinal requirements, a reevaluation of jurisdictional concepts is timely. Although there has been considerable discussion of long-arm statutes and their effects on convenience to parties, ${ }^{\circ}$ their use for choice of law through choice of forum has received scant attention. Thus, for current purposes as well, there is reason to explore a hypothetical case that exposes the full impact of traditional jurisdictional practices.

Utilizing examples in the areas of quasi in rem jurisdiction, divorce, and support hitigation, part I of this Comment discusses ways that

televised image of a presently testifying witness satisfy the hearsay test? His verbal inflection, his facial expressions, his hesitancy or other mannerisms are all open to observation, and cross-examination is possible. Does the sixth amendment protect as well some less tangible sense of immediacy that telecommunications may hamper?

There may well be cases where such concerns dictate that trial-by-television should not be made available-perhaps in some as a matter of law, in others at the discretion of the trial judge, and in yet others at the defendant's demand. While criminal cases and tort actions are probably the most deserving of a conservative approach, a large residue of cases exists where trial-by-television would both meet judicial fairness standards and better comport with the litigants' desires for convenience. Many contract and divorce cases surely fall into such a category.

Procedural rules are already responding to technology in a related area, where video tape has been endorsed as an especially effective method of recording depositions. $8 \mathrm{C}$. Wright \& A. Miller, Federal Practice and Procedure $\$ 2115$ (1970). In 1970, Rule 30(b)(4) of the Federal Rules of Civil Procedure was adopted and Rule 30(c) was amended, permitting federal courts, upon motion, to order that testimony be "taken stenographically or recorded by any other means ... ." 48 F.R.D. 459, 465-66 (1970) (emphasis added). Under the prior language, audio-visual recording was possible only through party stipulation. United States Steel Corp. v. United States, 43 F.R.D. 447, 450-51 (1968).

5. This discussion assumes that such differences will remain long after the single physical forum has ceased to be a nccessary condition for adjudication. Uniform legislation, even where enacted in the same form by several states, does not erase the differences that occur as the result of independent judicial systems, each free to formulate an independent interpretation of identical statutory language. Only the demise of the federal system or a comprehensive use of interstate compacts (which would subject incorporated legislation to uniform Supreme Court interpretation) could moot the choice of law issues that are a subject of this Comment. For a discussion of the potential for unified laws through the use of interstate compacts, see text accompanying notes 153-63 infra. While the prospect of trial-by-television may appear to some as unlikely as unification of law, the aim of this Comment is to promote reevaluation of current jurisdictional thinking. Consequently, trial-by-television serves primarily to focus attention on those relics of power that live on in current jurisdictional and choice of law practices.

6. See the articles cited in Comment, supra note 1 , at 300 n.3. 
assignment of jurisdiction has served purposes of policy allocation, ${ }^{7}$ evaluates the validity of this function of jurisdictional rules, and suggests that the time has come for direct confrontation of choice of law dilemmas. In part II, current and potential doctrinal formulations under the due process clause are considered, and an alternative rationale based on the full faith and credit clause is proposed. Part III deals witl specific problems of implementation. Practical ramifications of rule formulation in the areas of choice of law and jurisdiction are discussed. Their complexity leads to the conclusion that Supreme Court or congressional action, though permissible under the Constitution, is not the optimal means for constructing a new, integrated law of jurisdiction and choice of law. Although uniform legislation is considered and endorsed, need for Supreme Court review proinpts the conclusion that interstate compacts provide the most promising avenue for coordinated state efforts.

Throughout, the purpose is to raise questions and elucidate the implications of current practices. Although preferences are sometimes indicated for one structure or another, this Comment argues that intelligent results can be achieved in a variety of ways if the ramifications inherent in any given format are recognized and deliberately utilized. Accordingly, part I exposes sub silentio controls imposed by certain current jurisdictional practices and enumerates possible variations; the illustrations are given primarily for analytical, not persuasive, purposes. Similarly, although part III concludes that the full faith and credit clause provides a clearer doctrinal framework for developments in jurisdiction and choice of law, this Comment does recognize potential under a due process rubric. For, although labels retain importance as indicators of judicial history and style, they need not obscure functional similarities that can be obtained under either heading. On the other hand, although part II suggests that, conceptually, choice of law control by the Supreme Court or Congress is permissible, part III points out that what is doctrinally acceptable may be functionally disastrous, and argues that, here, resort to alternative means is best restricted to uniform legislation or, preferably, interstate compacts.

I

\section{Choice of Forum as Choice of Law: A Helpful Surrogate?}

7. The term "policy allocation" is used to denote more than allocation of substantive control of litigational issues. As discussed in text accompanying notes 8-61 infra, the availability of a jurisdictional base alone may express much more than considerations of convenience. The term thus incorporates both aspects of allocation. More precise definition is waived in lieu of the advantages of a somewhat nebulous term. See generally L. CARroll, Through the LookING-Glass 94-95 (Random House 1946). 
To counteract [forum shopping], choice of "a proper forum," i.e., a court which can properly apply its own policy . . . appears as the only remedy.

\section{A. Ehrenzweig}

\section{A. Choice of Law: An Exercise in Legislative and Judicial Default}

Choice of law was a fairly easy matter so long as the doctrine of vested rights retained its vigor: the law of the place would be applied. Although the decision as to where a cause of action arose was not always clearcut, ${ }^{9}$ territorial notions of sovereignty provided that once the correct geographical location had been identified, the question of applicable law was answered. This solution no longer seems inevitable. Indeed, the entire choice of law field is in flux, accompanied by a wide diversity in the rationales proffered by courts ${ }^{10}$ and commentators. ${ }^{11}$

At the same time, the minimum contacts test for in personam jurisdiction promulgated by International Shoe, ${ }^{12} \mathrm{McGee},{ }^{13}$ and Hanson ${ }^{14}-$ frequently satisfied in several forums-provides litigants with increased opportunity for clioice of forum. Continuing differences in substantive and choice of law formulations prompt the infamous "race to the courthouse" as the parties vie for favorable results. Fortunately, the contest does not necessarily end with service of process under the long-arm statute of a constitutionally acceptable forum. Yet even the aineliorative effects of a dismissal on grounds of forum non conveniens are secured only after more delay, expense, and uncertainty. ${ }^{15}$ Further confusion

8. Ehrenzweig, A Proper Law in a Proper Forum, 18 OKLA. L. Rev. 340, 350 (1965).

9. Characterization assumed the state of high art since often a single event could be assigned one location or another for choice of law purposes, depending upon which legal theory was advanced. See, e.g., Kilberg v. Northeast Airlines, Inc., 9 N.Y.2d 34, 172 N.E.2d 526, 211 N.Y.S.2d 133 (1961) (tort-contract distinction).

10. See, e.g., Willenbucher v. McCormick, 229 F. Supp. 659 (D. Colo. 1964) (lex fori); Reich v. Purcell, 67 Cal. 2d 551, 432 P.2d 727, 58 Cal. Rptr. 800 (1967) (governmental interests); Johnson v. St. Paul Mercury Ins. Co., 256 La. 289, 236 So. 2d 216 (1970) (vested rights); Auten v. Auten, 308 N.Y. 155, 124 N.E.2d 99 (1954) (center of gravity); Heath v. Zellmer, 35 Wis. 2d 578, 151 N.W.2d 664 (1967) (Leflar's theory).

11. See, e.g., Comments on Reich v. Purcell, 15 U.C.L.A.L. REv. 551 (1968) (symposium).

12. International Shoe Co. v. Washington, 326 U.S. 310 (1945).

13. McGee v. International Life Ins. Co., 355 U.S. 220 (1957).

14. Hanson v. Denckla, 357 U.S. 235 (1958).

15. Such a dismissal will foreclose any choice of law benefit the plaintiff had hoped to secure through choice of the dismissing forum. A. EHRENZwEIG, Conflicts IN A NUTSHELL $\$ 9-8$ (2d ed. 1970). In federal courts this is not necessarily the case, since the law of the transferor state ordinarily accompanies a case that is transferred under Rule 1404(a) of the Federal Rules of Civil Procedure. Van Dusen v. Barrack, 376 U.S. 612, 639 (1964). However, Van Dusen left open the question as to applicable law both when a plaintiff seeks transfer and when the original forum is so niconvenient that a state court at that location "would simply have dismissed the action on the ground 
may occur when concurrent litigation is possible in forums that apply differing laws. ${ }^{16}$ In Hanson $v$. Denckla, ${ }^{17}$ for example, simultaneous hitigation in two states produced continuing interaction as the parties in one court attempted to utilize injunctions ${ }^{18}$ and the effects of res judicata $^{19}$ to affect litigation in the other, and directly conflicting holdings ${ }^{20}$ eventually required Supreme Court resolution. ${ }^{21}$

There has been no attempt by Congress to modify the race or its uncertainties. The Supreme Court has shown only shightly less aversion to the issue, enunciating expansive jurisdictional standards ${ }^{22}$ and imposing a veto on state choice of law practice only when forum law was applied in a case involving no forum contacts other than the plaintiff's citizenship and the defendant's amenability to quasi in rem jurisdiction. ${ }^{23}$

\section{B. Jurisdiction as Policy Allocation: Some Current Practices}

It is to this situation, then, that Professor Ehrenzweig speaks when he suggests restructuring jurisdictional rules in order to assign cases to courtrooms that may appropriately apply forum policy. ${ }^{24}$ Under his theory, forum policy may, of course, dictate application of nonforum

of forum non conveniens." Id. at 640. The difference may therefore not be as great as it initially appears since there is clearly a lower threshold for achieving a transfer under Rule 1404(a) than for securing a state court disınissal on grounds of forum non conveniens.

16. Although other reasons of party convenience may also encourage concurrent hitigation, the expense entailed in multiple suits suggests that anticipated choice of law benefits are the primary incentive for this kind of forum shopping. Professor Ehrenzweig endorses this motivation: "[H]] is motive [for bringing two suits on the same cause of action in two forums] may be entirely legitimate, as where he desires to have his case tried under a more favorable law ...." A. Ehrenzweio, A TreAtise on THE CONFLICT OF LAws \$ 36, at 127 (1962).

17. 357 U.S. 235 (1958). The case concerned conflicting claims to $\$ 400,000$, part of the corpus of a trust estabhished in Delaware by a then-Pennsylvania domiciliary who later died while domiciled in Florida, where her will was admitted to probate.

18. The Florida court enjoined Mrs. Hanson's continued participation in the litigation taking place in Delaware. Id. at 242.

19. First, the legatees unsuccessfully urged the Florida decree as res judicata in the Delaware proceedings. Id. at. 242 . Later, the opposing parties urged, also unsuccessfully, that the Florida court owed full faith and credit to the decision of the Delaware court. Id. at 243.

20. Id. at 238 .

21. Id. at 256; cf. Treinies v. Sunshine Mining Co., 308 U.S. 66 (1939).

22. See, e.g., McGee v. International Life Ins. Co., 355 U.S. 220, 223 (1957); International Shoe Co. v. Washington, 326 U.S. 310, 316-19 (1945). But cf. Hanson v. Denckla, 357 U.S. 235, 251-53 (1958).

23. Home Insurance Co. v. Dick, 281 U.S. 397 (1930). The highpoint of constitutional control of choice of law under the due process clause, Dick proved to be little more than a hillock; its holding was narrowly construed in Hartford Accident \& Indem. Co. v. Delta \& Pine Land Co., 292 U.S. 143 (1934).

24. See note 8 supra and acconpanying text. 
law. ${ }^{25}$ Thus, in place of an approach that envisions several proper forums and is predicated on an assumption that the chosen forum can soinehow "find" the "appropriate" law, he suggests jurisdictional rules that will somehow designate an "appropriate" forum, which will then apply its own-the "appropriate"?-policy.

Two observations are in order: First, the need to define appropriateness remains. Professor Ehrenzweig's approach-choosing a forum, then leaving the choice of law chips to fall as they may-is functionally equivalent to choice of law, one step removed. Second, the utility of effecting choice of law consequences via this indirect, jurisdictional route appears doubtful. Although stated as separate considerations, they are but different aspects of a common problem: rational distribution of judicial business in a federal system. Disparate laws and jurisdictions are part and parcel of the federal system. Yet, social and commercial interdependence produces cases with multistate aspects that make hitigational efficiency and consistency desirable. The ordering of any system involves a priori value judgments; Professor Ehrenzweig's shift of emphasis from choice of law to in personan jurisdictional rules deserves reevaluation. Current jurisdictional practice in the related areas of quasi in rem, divorce, and support litigation highlights the potential as well as the limitations inherent in such policy allocation through assignment of forum.

\section{Quasi in Rem Jurisdiction}

Underlying quasi in rem jurisdiction is a desire to provide plaintiffs with additional opportunity for both choice of forum and direct access to defendants' assets. The jurisdictional base itself confers benefits beyond those available under in personam rubrics. Professor Seidelson $^{26}$ identifies a "now you see it, now you don't" application of New York's Seider $v$. Roth ${ }^{27}$ rationale that exposes the intended beneficiaries of quasi in rem jurisdiction: resident plaintiffs. ${ }^{28}$

In Seider the New York plaintiff was able to secure quasi in rem jurisdiction over a nonresident defendant through attachment of an intangible res-the obligation of an out-of-state insurer doing business in New York to defend and indemnify the defendant under the terms of an automobile insurance policy. ${ }^{29}$ Logically, once assigned a situs in New York, this res should be equally available to attachment by nonresident

25. Ehrenzweig, supra note 8 , at 348-49.

26. Seidelson, Seider y. Roth, et seq., 39 Geo. Wash. L. REv. 42 (1970).

27. 17 N.Y.2d 111, 216 N.E.2d 312, 269 N.Y.S.2d 99 (1966).

28. Seidelson, supra note 26, at 60 ("[T]he overriding reason for Seider jurisdiction is to provide a local forum for New York residents").

29. 17 N.Y.2d at 112,216 N.E.2d at 313,269 N.Y.S.2d at 100. 
plaintiffs. However, this consequence was avoided in Vaage v. Lewis, ${ }^{30}$ where the plaintiff was a Norwegian citizen, through dismissal on grounds of forum non conveniens. ${ }^{31}$ Since New York courts do not employ forum non conveniens against New York plaintiffs, ${ }^{32}$ this technique substantially reserves Seider benefits for forum residents. ${ }^{33}$

New York's approach has several implications. First, there is no adequate rationale for limiting the availability of a forum non conveniens defense to attachment of intangibles. The New York courts imply that Seider-like quasi in rem cases require special treatment because they involve a garnisliee's due process right to be free of garnishment in a state with which lie lias had insufficient contact. ${ }^{34}$ Under a minimum contacts test, lowever, forum citizenship of the plaintiff cannot provide the requisite defendant-forum contact and is, therefore, generally thought insufficient to autoinatically sustain jurisdiction ${ }^{35}$ New York's rationale confuses the discretionary nature of a forum non conveniens dismissal with the lack $a b$ initio of constitutionally permissible jurisdiction in a case that fails the minimum contacts test.

Second, extending a forum non conveniens defense to quasi in rem jurisdiction based on the presence of tangible assets would largely ehminate quasi in rem as a jurisdictional base distinguishable from in personain jurisdiction; the fairness issues raised by a forum non conveniens motion are apparently identical under either label. ${ }^{36}$

30. 29 App. Div. 2d 315, 288 N.Y.S.2d 521 (1968).

31. The court stated that the convenience of the court system, and not that of the litigants, was the determining factor. It also cited Hanson v. Denckla, 357 U.S. 235 (1958), as support for its conclusion that "an exercise of jurisdiction in this case would deprive the defendants of basic due process . . ." 29 App. Div. 2d at 318, 288 N.Y.S.2d at 525. Analysis suggests that use of the word "defendant" in place of an apparently clear reference to the garnishee insurance company is significant: despite its protestations, analytically the court is treating the garnishee as the true defendant in an in personam direct action claim. Whatever the doctrinal machinations, of significance here is the pronounced plaintiff bias these cases share with more traditional quasi in rem proceedings.

32. See A. EHRENZWEIG, supra note 16, at $\$ 35 \mathrm{n} .5$ and cases cited therein.

33. It is possible that a forum non conveniens motion would be unsuccessful against a nonresident plaintiff in litigation involving an accident that occurred in New York.

34. See note 31 supra.

35. Rather, balancing of the type exhibited in McGee v. International Life Ins. Co., 355 U.S. 220 (1957), as arguably restricted by Hanson v. Denckla, 357 U.S. 235 (1958), seems necessary. Confusion stems from the application of due process notions of minimum contacts to the more traditional quasi in rem issue of a debtor's presence. See von Mehren \& Trautman, Jurisdiction to Adjudicate, 79 HARv. L. REv. 1121, 1140 (1966).

36. Such a result is perhaps desirable. See note 40 infra. In Vaage v. Lewis, the court acknowledged that "the defendants have been understandably reticent about advancing theories like forum non conveniens, public policy and lack of sufficient jurisdictional contacts (all out of fear of unintentionally effecting an in personam 
Third, equal protection questions arise once marked preference for forum residents im the attachment of intangibles is apparent, since New York does not otherwise require that the plaintiff in a quasi in rem action be a New York resident. ${ }^{37}$ Although the same objection applies to New York's refusal to apply forum non convemiens control to im personam actions brought by forum residents, there is a difference: the in personam practice is uniform; in quasi in rem, only some actions (those involving contingent obligations) partake of this resident-protective device. $^{38}$

A final implication, of primary importance to this Comment, follows from the prior three: unless carefully analyzed and structured, jurisdiction is a clumsy tool for purposes of policy allocation. Specifically, given its concern for resident plaintiffs, ${ }^{39}$ quasi in rem jurisdiction over tangibles has achieved overbroad results-nonresidents, too, gain access to forum courts. Equally important, quasi in rem's jurisdictional label provides an aura of legitimacy that has impeded reevaluation of both the need for this form of plaintiff bias and its constitutionality. ${ }^{40}$

Indeed, insensitivity and imperviousness are general characteristics of jurisdictional rules. In divorce jurisdiction, these qualities intersect with another factor-choice of law-and the resulting ossification is noteworthy.

\section{Divorce}

Two kinds of policy allocation are embodied in the domicihary basis of divorce jurisdiction. As in quasi in rem jurisdiction, the first policy is to provide a forum that does not depend on personal jurisdiction

jurisdictional base) . . . 29 App. Div. 2d 315, 318, 288 N.Y.S.2d 521, 524 (1968). The reference apparently is to a blurring of the distinction between quasi in rem and in personam rather than to any danger of unintentionally entering a general appearance. See notes 31,35 supra.

37. Seidelson, supra note 26 , at 62 , discussing N.Y. Crv. PRAc. $\$ \S 6201-26$ (McKinney 1963).

38. Challenges to this distinction would probably be met through a doctrinal realignment that asserts what commentators have surmised: the in personam nature of Seider-like proceedings. The alternate solution would be to extend New York's forum non conveniens practice to all quasi in rem cases, tangibles and intangibles alike.

39. See note 28 supra and text accompanying notes 26-33 supra.

40. Need for quasi in rein jurisdiction as traditionally forinulated can be questioncd in view of the increased availability of in personam jurisdiction that exists in the wake of International Shoe. Constitutional questions are discussed at notes 31,35 supra and accompanying text. Perhaps, as suggested by von Mehren and Trautman, a more satisfactory structure could be patterned on French practice, which employs quasi in reln jurisdiction for the limited purpose of securing assets agamst dissipation and concealment. von Mehren \& Trautman, supra note 35, at 1141. See generally A. von Mehren \& D. Trautman, The Law of Multistate Problems 695-96 (1965). 
over the defendant. ${ }^{41}$ The second is to effect an allocation among the states of the substantive control of divorce actions. This occurs because once divorce jurisdiction is asserted, forum law is applied automatically as a corollary of the proceeding's in ren label. ${ }^{42}$ Originally, this label was applied to permit litigation in the defendant's absence. ${ }^{43}$ Through fictional characterization of the marital relationship as a res, the plaintiff was able to secure a change in status although personal jurisdiction over the defendant could not be obtained. ${ }^{44}$

A danger that exists in tying clioice of law consequences to jurisdictional requirements is highlighted in Alton v. Alton. ${ }^{45}$ Rather than begin with the in rem nature of the proceedings and deduce the application of forum law, the court began with a decision to apply forum law and inferred that their clioice of law could be guaranteed only through an in rem proceeding based on domicile ${ }^{46}$ - the traditional test for presence of the inarital res. ${ }^{47}$ Striking down an attempt by the Virgin Islands legislature to base divorce on other grounds, ${ }^{48}$ the court of appeals inajority apparently failed to recognize the distinction between judicial jurisdiction and application of forum law. Consequently, Judge Goodrich used reasoning appropriate to a choice of law decision, although the issue was one of jurisdiction: "We think that adherence to

41. A. EHRENZWEIG, supra note $16, \$ 71$, at 237.

42. Id. § 72 , at 241 .

43. Id. at $241-42$.

44. Id. In Mullane v. Central Hanover Bank \& Trust Co., 339 U.S. 306 (1950), Mr. Justice Jackson observed, "American conrts have sometimes classed certain actions as in rem because personal service of process was not required, and at other times have held personal service of process not required because the action was in rem." Id. at 312 .

45. 207 F.2d 667 (3d Cir. 1953).

46. Id. at 677. In an earlier case, Williams v. North Carolina, [I] 317 U.S. 287 (1942), which leld domicile a sufficient jurisdictional basis for ex parte divorces, the Supreme Court left open the question as to other possible bases for divorce jurisdiction:

Domicil of the plaintiff ... [is] essential in order to give the court jurisdiction which will entitle the divorce decree to extraterritorial effect, at least when the defendant has neither been personally served nor entered an appearance.

Id. at 298-99 (emphasis added).

47. A. EHRENZWEIG, supra note $16, \S 71$, at 237.

48. Bill No. 55, 17th Legislative Assembly of the Virgin Islands, passed May 19, 1953, approved May 29, 1953, amending $\$ 9$ of the Divorce Law of 1944. The provision at issue was set forth by the court:

[I] the plaintiff is within the district at the time of the filing of the complaint and has been continuously for six weeks immediately prior thereto, this shall be prima facie evidence of domicile, and where the defendant has been personally served within the district or enters a general appearance in the action, then the Court slall have jurisdiction of the action and of the parties thereto without further reference to domicile or to the place where the marriage was solemnized or the cause of action arose.

207 F.2d at 669 (emphasis added). 
the domiciliary requirement is necessary if our states are really to have control over the domestic relations of their citizens." ${ }^{\text {"49 }}$

As Judge Hastie suggested, the court's concern could have been met instead by a requirement that the law of the place of domicile be applied in divorce cases, regardless of the jurisdictional base. ${ }^{50}$ Indeed, such a choice of law rule would secure application of the same law as jurisdiction based on domicile, yet allow in personam adjudications where convenience to the parties would be better served.

Under current practice, an in personam jurisdictional base is necessary for resolution of the property and financial aspects of a divorce. ${ }^{51}$ Accordingly, a party obtaining an ex parte divorce unust pay for the advantage of being able to change the applicable law through a change in domicile by litigating twice if the defendant is not served within the forum or does not enter a general appearance. For example, a woinan may move from New York to Nevada and obtam an ex parte divorce under the Nevada law, but must then return to New York to litigate settlement matters. ${ }^{52}$

If personal jurisdiction with a choice of law restraint were permissible, she could retain application of her Nevada domiciliary law concerning marriage dissolution although litigating both the dissolution and financial details in a single New York proceeding. ${ }^{53}$ Obviously, the

49. Id. at 676.

50. Id. at 684-85 (Hastie, J., dissenting). One function of the domiciliary requirement has been to allow parties who could afford to establisl domicile in a state with favorable divorce laws an opportunity to avoid the strictures of the law of the state of original domicile. Imposing a cloice of law restraint that turns on domicile retains this ability to cliange the applicable law by clianging domicile.

It is interesting to note that an Australian court required that the domiciliary state grant full faith and credit to a sister-state divorce decree purportedly based onalthough clearly lacking-domiciliary jurisdiction. Apparently determinative was an absence of danger that the lolding would encourage forum shopping. The court discussed the relevant American cases but said that collateral attack need not be provided since Australian divorce differed only slightly from state to state. See the critical discussion of Harris v. Harris, [1947] Vict. I.R. 44, in Cowen, Full Faith and CreditThe Australian Experience, 6 Res JudicATAE 27, $41-48$ (1952) and Cowen, The Conflict of Laws: The Experience of the Australian Federation, 6 VAND. L. REV. 638, 647-50 (1953), Australia lias since passed a National Divorce Law, discussed in 74 HARV. L. REV. 424 (1960).

51. See Estin v. Estin, 334 U.S. 541, 547-49 (1948).

52. Id.

53. In contrast, under Judge Hastie's approach, it appears that New York law would be applied (as is currently the case) if she, a domiciliary of Nevada, comes to New York in order to divorce a forum domiciliary. Thus, she is given the option of Nevada law in Nevada or New York law in New York unless her husband obtains a divorce first, thereby precluding her choice. A choice of law rule that allows her to bring Nevada law with her to New York seems somewhat strange at first: if she institutes suit, Nevada law applies; if her husband sues first, New York law applies. Yet this race is exactly what current practice condones; only the courtroom differs. Part III of this Comment suggests that interstate compacts might provide a more rational allocation between New York and Nevada divorce laws. 
distaste of New York courts for application of Nevada divorce law would be great, and the problems of ensuring faithful interpretation would be real..$^{54}$ Yet the substantive result would be the same, the judgment would not be subject to the dangers of collateral attack that accompany an ex parte divorce, the husband would have a convenient opportunity to defend rather than be forced into a choice between litigation in Nevada and the vagaries of a later attempt at collateral attack of the Nevada decree, and the cost of one action in place of two would probably be less.

Sucl an in personam alternative would provide another option that is of special relevance to the jurisdictional problems that currently attend divorces involving military personnel ${ }^{55}$ and other highly mobile parties. ${ }^{50}$ Litigation could take place at the residence of the defendant, or in any forum where personal jurisdiction is obtainable, if both parties had left the state of former domicile but lacked new domiciles of sufficient duration for divorce purposes.

A hypothetical divorce-by-television illustrates problems posed by such direct choice of law control. Assume the separation of a couple domiciled in Georgia. The wife returns to the home of her parents in Oregon; the husband assumes a new position in Florida. As neither spouse has yet acquired a new domicile of sufficient duration for divorce purposes, the law of Georgia, the state of marital domicile, would be applicable. The wife brings suit in Oregon and acquires jurisdiction over her husband. ${ }^{57}$ Given an in personam jurisdictional base subject

54. See text accompanying notes 58, 71-75 infra.

55. See A. EHRENZweig, supra note $16, \S 71$, at $239, \S 72$, at 241.

56. See D. Currie, Suitcase Divorce in the Conflict of Laws, 34 U. CHI. L. REv. 26, 48 (1966).

57. The means of acquiring in personam jurisdiction deserve reevaluation. Given a convenient opportunity to defend, it would be irrational to perpetuate a system that allows transient jurisdiction [see generally Ehrenzweig, The Transient Rule of Personal Jurisdiction, 65 Y ALE L.J. 289 (1956)] but prohibits personal service for divorce purposes outside the forum state. In picturephone cases, nationwide service of process would clearly be appropriate. With an in personam jurisdictional base, domiciliary service would be possible in Florida, in this hypothetical, since the domiciliary test for service of process in the defendant's absence [Milliken v. Meyer, 311 U.S. 457 (1940)] is less stringent than the domiciliary test for purposes of divorce jurisdiction. A. EHRENZWEIG, supra note 16 , § 72 .

Three caveats are in order. First, because witnesses may be located elsewhere, a convenient defense is not necessarily made possible by the ability to defend at home. Second, a new theory of jurisdiction must remain sensitive to the continuing validity of a preference for in-person presentation of testimony and exhibits. Sec note 4 supra. Third, the scope of the proceedings may require limitation, for example, by curtailing the availabihty of cross-complaints. See note 64 infra.

Puzzling questions that arise in efforts to re-tailor current jurisdictional concepts to picturephone cases emphasize the need for a total revanuping of in rem jurisdictional doctrine. For example, even given a domiciliary jurisdictional basis for our hypothetical, trial-by-television raises a basic uncertainty as to the location of the forum for 
to a choice of law restraint, all aspects of the divorce are litigable and the same law would apply as in an action based on domiciliary jurisdiction in Georgia.

Picturephones and our liypothetical would permit the Georgia judiciary to preside over the application of Georgia law; other cases require more prosaic means of ensuring satisfactory application of the "chosen" law. In Fauntleroy v. $\mathrm{Lum}^{58}$ the full faitl and credit clause compelled Mississippi enforcement of a Missouri judgment which incorporated a reading of Mississippi law that could only have been the product of deliberate distortion or gross misinformation. Quite aside from the issue of sister-state enforcement of judgments offensive to forum policy is the point that choice of law directives will be effective only if accompanied by competent—or at least good faith-application of the designated law. ${ }^{50}$

This discussion of an alternative in personam base for divorce jurisdiction does not reach two issues that should be fundainental to any revamping of divorce practice. First, it does not evaluate the suitability of applying domiciliary law to this adjudication of status. Second, if domiciliary law is appropriate, it does not necessarily follow that its definition should turn on varying residency standards or a domiciliary intent requirement. For example, a standard residency period could remove the litigious intent question yet preserve an acceptable nexus between the parties and the applicable law. ${ }^{60}$ Although the second question is especially difficult, its resolution appears more likely once freed

jurisdictional purposes. If the parties are in Oregon and Florida and the judge is in Georgia, is Georgia the site of the forum? If so, since the hypothetical provides that neither party has yet acquired a new domicile sufficient for divorce purposes, does the marital domicile in Georgia continue to provide in ren jurisdiction? Or is Florida, too-or instead-a forum, and personal jurisdiction for property settlement purposes therefore available? In proceedings under the Uniform Reciprocal Enforcement of Support Act, the responding court does acquire personal jurisdiction over the defendant. UNIFORM RECIPROCAL ENFORCEMENT OF SUPPORT ACT $\$ 22$ (1952 version) [hereinafter cited as URESA]. However, under URESA the judge also presides in the responding forum, as distinguished from our hypothetical.

58. 210 U.S. 230 (1908).

59. This is especially relevant if the choice of law is externally imposed, creating a greater possibility that it will be offensive to the forum. Of course, interstate compacts or congressional imposition of such rules through legislation founded on the full faith and credit clause would provide Suprene Court supervision. See text accounpanying notes 126-31, 153-63 infra. Or, if personal jurisdiction is constitutionally permissible in divorce cases only when accompanied by a choice of law restraint, supervision by the Court is also in order. The role would not be entirely novel; since Erie R.R. v. Tompkins, 304 U.S. 64 (1938), the Court has overseen the interpretation of state law by lower federal courts. As to self-restraint in the form of uniform legislation, see text accompanying notes 70-75 infra.

60. UNIFORM MARRIAGE AND DivorCE ACT $\$ 302(a)$ (1) (1970) (Handbook of the National Conference of Commissioners on Uniform State Laws). 
of the jurisdictional mystique that has so beleaguered American divorce law.

As these examples suggest, jurisdiction is a cumbersome and inflexible tool. Its resistance to change is intensified when choice of law is secured through jurisdictional labels. Thus, in divorce proceedimgs, although personal jurisdiction is required for the resolution of support, property, and custody matters, anxiety over choice of law has prevented jurisdictional reform. ${ }^{61}$ Revision seems nonetheless inevitable; as judicial telecommunications become available, it will appear increasingly ludicrous to eniploy 19th-century in rem fictions as a bar to needs created by 20 th-century mobility.

\section{Support}

Rethinking jurisdictional practices with a view to party convenience and forthright resolution of choice of law issues raises a host of new considerations. Of central concern is the feasability of implementing choice of law provisions. Fauntleroy v. Lum ${ }^{62}$ displayed Missouri's displeasure with a doctrinally imposed choice of law; seemingly, self-determination in the form of a model act would overcome this difficulty. Experience under the Uniform Reciprocal Enforcement of Support Act (URESA) is relevant.

Adoption of this Act has revolutionized procedures in all states. ${ }^{03}$ The product of pressures that would not wait for the technological multistate forum hypothesized above, it provides an important example of potential techniques and pitfalls for jurisdiction of the future. To place the relevant aspects of URESA in perspective, assume the following: Once again a family separates in Georgia. This time the wife and children return to Oregon while the husband remains for some time in Georgia. Before moving to Florida, he defaults in his support obligations. Later, his wife institutes support proceedings. Although an action for support requires in personain jurisdiction, the wife need not travel to Florida or secure transient jurisdiction through service of process in some other more convenient forum where her husband is temporarily present. Instead, she may file a complaint in Oregon and jurisdiction will be secured over her husband by the "responding" Florida court. ${ }^{64}$

61. See note 114 infra.

62. 210 U.S. 230 (1908), discussed in text accompanying note 58 supra.

63. By 1957 the original version of URESA or a substantially similar act had been adopted by all 50 states, the District of Columbia, the Coinmonwealth of Puerto Rico, and most of the other areas subject to the jurisdiction of the United States. REVISED UNIFORM RECIPROCAL ENFORCEMENT OF SUPPORT ACT, Commissioners' Prefatory Note, at 223 (1968 Handbook of the National Conference of Commissioners on Uniform State Laws) [heremafter cited as REviSED ACT].

64. URESA $\S \S 13,15,17(4)$; REVISED ACT $\S \S 14,16,18(\mathrm{~b})$. Although per- 
Here is the first example of litigation unconstrained by a sole plyysical forum. For our purposes, it is significant that the legislation establishing this jurisdictional multistate forum incorporates-necessarily-choice of law provisions. ${ }^{65}$ Consequently, Georgia law will determine her husband's obligations prior to his move to Florida, ${ }^{66}$ and she will be subjected to the same dangers of judicial infidelity discussed in the divorce hypothetical above. If Florida support decrees are modifi$a b l e,{ }^{67}$ she need not be concerned that an inappropriate, detrimental application of Georgia law will produce a judgment entitled to full faith and credit under the Constitution. ${ }^{88}$ This is cold comfort, however, since other states do grant a form of faith and credit to foreign support orders under a provision of the Act, ${ }^{69}$ and, under a modifiable decree,

sonal jurisdiction may be acquired under these sections, the Act specifically limits the effect of such jurisdiction: "Participation in any proceeding under this Act does not confer jurisdiction upon any court over any of the parties thereto in any other proceeding." REviSED ACT $\$ 32$ (incorporating minor wording changes from URESA \$ 28). The California version of this section was at issue in Mehrstein v. Mehrstein, 245 Cal. App. 2d 646, 54 Cal. Rptr. 65 (2d Dist. 1966).

65. Duties of support applicable under this law [act] are those imposed or imposable under the laws of any state where the obligor was present during the period for which support is sought. The obligor is presumed to have been present in the responding state during the period for which support is sought until otherwise shown.

URESA $\$ 7$ (einphasis added). This wording incorporates a significant revision of the 1950 version of the Act; the clranges and rationale are set forth in the Commissioners' Note:

Section 7 was amended by striking the words "or where the obligee was present when the failure to support commenced, at the election of the obligee" after the word "sought" and by adding the last sentence. ... The last part of Section 7 as originally adopted was drafted to take care of the situation where the wife did not know the whereabouts of her hnsband. It was never intended that she should have an absolute right to choose the applicable law as her interest might dictate.

Id. $\$ 7$, Commissioners' Note. In California, the wording of the earlier version was held to place the choice of law issue at the election of the obligee. Mehrstein v. Mehrstein, 245 Cal. App. 2d 646, 54 Cal. Rptr. 65 (2d Dist. 1966). Ambiguity remains in continued use of the word "any" (italicized in section 7 as set forth above). Opportunity for choice of law by the defendant through choice of residence is discussed in A. EHRENZWEIG, supra note 15 , at $\$$ 38-1, 38-2.

66. This is because the 1952 version of the Act is in effect [see note 65 supra]. Fla. STAT. ANN. \& 88.081 (1964). Under the 1950 URESA version of section 7, were it applicable, she could elect Oregon law. See note 65 supra.

67. This is possible under URESA. See note 69 infra. In practice, support orders are usually inodifiable. R. CRAmton \& D. CURRIE, Conflict of LAws 631 (1968); Restatement (Second) of Conflict of LAws $\$ 109$, comment $a$ (1971).

68. Sistare v. Sistare, 218 U.S. 1 (1910); Restatement (SeCond) of Conflict of LAWs \$ 79, comment $c$ (1971).

69. This is so in states that provide for registration of foreign support orders under inore recent versions of the Aet. REvised ACT $\$ 2(n)$, with only slight changes in wording from the 1958 version of URESA, states:

"Support order" means any judgment, decree, or order of support in favor of an obligee whether teinporary or final, or subject to inodification, revocation, or remission, regardless of the kind of action or proceeding in which it is 
she will be bound within Florida until changed circumstances justify renewed litigation. ${ }^{70}$ The question becomes: is it foolish for her to fear that Florida might be less than willing to apply a faithful rendition of the law selected by its own legislatively prescribed choice of law rules?

Pennsylvania ex rel. Department of Public Assistance v. Mong ${ }^{71}$ suggests that her apprehensions may be well founded. In Mong, an Ohio court refused on policy grounds to apply Pennsylvania law, appropriate under URESA, ${ }^{72}$ because to do so would impose an obligation on the defendant that Ohio law would not sustain. ${ }^{73}$ The logical fallacy is clear. Statutory choice of law provisions that lead to nonforum law express legislative consent to application of law different from that of the forum. Sucl differences are most likely to exist precisely because of differences in underlying policy judgments. It is therefore elliptical in such cases for the forum to refuse application of a nonforum law because it is inconsistent with forum policy.

Although Mong may be an aberration, which increasingly sophisticated courts will refuse to imitate, ${ }^{74}$ it is a reminder of the Achilles' leel of uniform legislation. For, once a court refuses to follow the dictates of its own legislation, the plaintiff is unable to appeal. ${ }^{75}$ Nevertheless, uniform legislation does remain important as an extraconstitutional medium for change. ${ }^{78}$

Study of URESA, then, suggests that while it is possible to integrate jurisdictional and choice of law processes, attention must be given

entered.

The effect given a sister-state order is defined in section 40(a):

Upon registration the registered foreign support order shall be treated in the same manner as a support order issued by a court of this State. It has the same effect and is subject to the same procedures, defenses, and proceedings for reopening, vacating, or staying as a support order of this State and may be enforced and satisfied in like manner.

REvised ACT \& 40(a) (einphasis added). Similar treatment was provided for in URESA $\$ 38$ (1958 version).

70. R. CRAmTon \& D. CuRrie, supra note 67, at 631.

71. 160 Ohio St. 455,117 N.E.2d 32 (1954).

72. This was appropriate because the language of the Ohio statute conformed to the original version of section 7 of URESA, which is discussed in note 65 supra. OHIo Rev. CODE ANN. $\$ 3115.03$ (Baldwin 1953).

73. 160 Ohio St. at 458,117 N.E.2d at 33.

74. Unfortunately, there is at least one subsequent case that is consistent with the philosophy exhibited in Mong. In California Dep't of Mental Hygiene v. Judd, 45 N.J. 46, 211 A.2d 198 (1965), the flip side of the coin was displayed: A New Jersey court refused application of its own law when it appeared that it might he more beneficial to the California plaintiff than the alternative choice of California law that was provided for under the New Jersey statute.

75. U.S. CoNST. art. III, $\$ 2$. For a discussion of interstate compacts, which would give such a right of appeal, see text accompanying notes 153-63 infra.

76. See text accompanying notes 148-52 infra. 
to the full faith and credit requirements that attend final decrees and to the reluctance of some courts to apply nonforum law.

\section{II}

\section{Constitutional Rationales}

If improved consistency in litigation involving multistate elements is to be achieved, and if courts are to utilize the opportunity for increased efficiency and convenience to parties through telecommunications, the lessons of quasi in rem, divorce, and support jurisdiction are germane: first, cumbersome, overmclusive features that are insensitive to choice of law consequences must be avoided; second, increased responsiveness to changing needs is essential. If traditional jurisdictional techniques, supplemented by choice of law directives, are to provide a framework adaptable to both conventional and media trials, clarification of the relevant value judgments and interstate relationships is needed. It is, of course, natural to look to the document that established our federal systeni for a solution to problems that are inherent in federalism. ${ }^{77}$ While the due process clause has played a primary role in jurisdictional inatters for almost a liundred years, ${ }^{78}$ constitutionally based choice of law doctrine - the little that has been enunciated-lias taken a faltering path, bounded sometimes by the due process clause ${ }^{79}$ and sometimes by the full faith and credit clause. ${ }^{80}$

\section{A. Due Process}

Difficulties that flow from existing doctrines under the due process clause have been discussed in part I and can be summarized briefly: as a choice of law control, due process permits uncertainty through an absence of restraints. ${ }^{81}$ And the minimum contacts formula provided by due process as a test for long-arm jurisdiction promotes uncertainty. ${ }^{82}$ At the same time, current practice retains two mappropriate features of

77. That these problems are indeed part and parcel of federalism has been pointed out:

A federal system not only mvites but depends for its vitality on conditions

that produce choice-of-law problems. . . .

... The allocation of law-making competence involved as between states is inherently and unquestionably a federal problem.

A. von MeHREN \& D. TRAUTMAN, supra note 40 , at 1218.

78. The seminal language was dictum by Mr. Justice Field. Pennoyer v. Neff, 95 U.S. 714, 733 (1877). Although Neff's property was attached in 1865 and sold pursuant to judgment in 1866 [Id. at 715-16], the fourteenth amendment did uot apply, as it was not ratified and certified until 1868.

79. See note 23 supra.

80. See note 117 infra.

81. See note 23 supra and accompanying text.

82. See notes $12-21$ supra and accompanying text. 
outdated dogma: quasi in rem jurisdiction ${ }^{83}$ and transient jurisdiction ${ }^{84}$ (personal jurisdiction acquired through personal service within the forum). In these two areas power-not fairness-remains the foundation for jurisdiction. Yet, potential development in due process notions deserves evaluation. There is, after all, reason to hope that broader application of the minimum contacts test will eventually undereut the objectionable foundations of both transient and quasi in rem jurisdiction. This can come through recognition that this test, which defines jurisdiction in terms of the degree and relevance of the defendant's contact with the forum, should apply consistently to individuals-to both their persons and possessions. ${ }^{85}$

Throughout its development, due process has dealt exclusively with the relationship of private parties to the judicial system qua government. Setting aside considerations of notice and fair hearing, so long as Pennoyer $v$. Neff ${ }^{36}$ retained full vigor, what one state could require of an individual was viewed as a function largely of what other states would allow. Certainly any return to this precedent would be anomalous in the searcli for a doctrine to serve the demands of an era in which power will have lost all significance. It is not in the relationship of man to goverument that groundwork is required.

One might expect to find whatever due process potential exists for future needs in the area of choice of law. There too, however, the due process rationale has been couched in terms of fairness between parties and government. ${ }^{87}$ Yet URESA and our trial-by-television hy-

83. See notes $26-40$ supra and accompanying text.

[L]abeling . . . the jurisdiction asserted in Harris v. Balk and its progeny as "jurisdiction quasi in rem" tends to conceal the naked power analysis of the opinion of the Court in that case and provides as well a superficially attractive explanation for a result that resists justification in any balanced and considered analysis.

von Mehren \& Trautman, supra note 35, at 1165 . Mr. Justice Peckhain's words were, "Power over the person of the gamishee confers jurisdiction on the courts of the State where the writ issues." Harris v. Balk, 198 U.S. 215, 222 (1905).

84. Ehrenzweig, supra note 57. But see von Mehren \& Trautman, supra note 35 , at 1138:

[T]he presence test can be explained-and largely justified-as simply a convenient identifying element that almost invariably signals a congeries of other significant affiliations with the forum that would, upon proper analysis, ground jurisdiction. Looked at this way, it is a simple test obviating detailed inquiry in each case and a consequent increase in litigation.

85. Under current practice, only long-arm jurisdiction employs the minimun contacts test vis-à-vis individuals. Although not couched in mininum contacts terms, similar forum contact does in fact undergird true in rem actions and personal jurisdiction based on individual or corporate domicile.

86. 95 U.S. 714 (1877).

87. The Restatement of Conflicts does, however, snggest the consideration of factors that relate to "the needs of the interstate and international systenn" and "the relevant policies of other interested states" in cases where there is no rclevant, consti- 
pothetical point out that guides are also needed when a number of potentially applicable laws meet stringent fairness tests.

Perhaps the strongest suggestion that due process is equal to the task lies in the doctrine's remarkable evolution over the past 94 years $^{88}$ as it has accommodated jurisdictional criteria to changing patterns of interstate activity. Movement from rigid territorial notions through consent fictions ${ }^{89}$ to the current minimum contacts basis for long-arm statutes has exhibited judicial willinguess to reevaluate the doctrine's conceptual underpinnings. Yet, in the face of its consistent emphasis on the relationship of the individual to the state, a predilection for change does not necessarily indicate that due process doctrine is well suited to regulate relationships among the states.

Probably the most hopeful indication of appropriate due process growth was exhibited in Buckeye Boiler Co. v. Superior Court, ${ }^{90}$ a California case. Traditionally, those states that employ the doctrine of forum non conveniens make an initial assertion of jurisdiction and then consider issues of party and litigational convenience under a subsequent inotion for discretionary dismissal. In Buckeye, what has generally been a two-step procedural process was reduced to one as convenience factors were weighed in the original determination of jurisdiction. Rather than simply tally defendant-forum contacts, the court considered features that would argue against-as well as in favor of-litigation in the forum. ${ }^{01}$ While this foreshadows more sophisticated, less rapacious, determinations of jurisdiction, which can accommodate both matters of party convenience and litigation-related factors such as proximity to witnesses and evidence, applying a due process label to the Buckeye

tutional, state statutory language on choice of law. RESTATEMENT (SECOND) or CONFLICT OF LAWS $\$ 6(2)$ (a),(b) (1971).

88. Pennoyer $v$. Neff was decided in 1877.

89. See, e.g., Hess v. Pawloski, 274 U.S. 352 (1927) (nonresident motorist statute).

90. 71 Cal. 2d 893, 458 P.2d 57, 80 Cal. Rptr. 113 (1969), noted in The Supreme Court of California 1968-1969, 58 CALIF. L. Rev. 80, 142-54 (1970).

91. Once it is established that the defendant lias engaged in activity of the requisite quality and nature in the forum state and that the cause of action is sufficiently connected with this activity, the propriety of an assumption of jurisdiction depends upon a balancing of the inconvenience to the defendant in having to defend itself in the forum state against both the interest of the plaintiff in suing locally and the interrelated interest of the state in assuming jurisdiction. In other words ... [the question] mvolves both a consideration of fairness to the plaintiff and a determination of ... "forum conveniens."

71 Cal. $2 \mathrm{~d}$ at 899,458 P.2d at 62, 80 Cal. Rptr. at 118 (emphasis added; citations omitted). This approach is consistent with Judge Learned Hand's statenient that "the controlling consideration ... [involves] an estimate of the inconveniences which would result froin requiring [a corporation] to defend, where it has been sued." Hutchinson v. Chase \& Gilbert, 45 F.2d 139, 141 (2d Cir. 1930), quoted in International Shoe Co. v. Washington, 326 U.S. 310,317 (1945). 
process would be deceptive. Indeed, consistent with current due process doctrine, which relies on enlightened self-restraint rather than directed interstate coordination, ${ }^{92}$ the Buckeye court did not suggest that its early consideration of the second-stage issues ${ }^{93}$-although appropriate-was constitutionally compelled. ${ }^{94}$ Arguments can be made, however, that the full faith and credit clause does require the second-stage balancing exhibited in Buckeye. ${ }^{95}$

\section{B. Full Faith and Credit}

Responsibility for allocating spheres of legal control among member states of a federal system cannot sensibly be placed elsewhere than with the federal government.

None would dispute that the Constitution gives the federal government the power necessary to discharge the allocation function. The full-faith-and-credit clause of article IV both sets forth the cryptic substantive standard and expressly confers legislative power to implement it.

$$
\text { W. Baxter }{ }^{96}
$$

Although Professor Baxter may have been overly optimistic in his assessment of popular understanding of the full faith and credit clause, ${ }^{97}$ history supports his thesis. Modeled on article IV of the Articles of Confederation, ${ }^{98}$ which, in turn, was patterned after earlier colonial statutes, ${ }^{99}$ the clause reads:

92. For a jaundiced view of self-restraint as exhibited in choice of law matters, see the discussion of Pennsylvania ex rel. Dep't of Pub. Assistance v. Mong and California Dep't of Mental Hygiene v. Judd at notes 68-74 supra and accompanying text.

93. See note 91 supra.

94. The new California jurisdiction statute subtly undercuts Buckeye; its explicit provision for forum non conveniens motions apparently dictates a two-step procedure. Cal. Code Crv. Pro. $\S \S 410.10,410.30$ (West Supp. 1971).

95. See text accompanying notes 126-30 infra.

96. Baxter, Choice of Law and the Federal System, 16 STAN. L. Rev. 1, 23 (1963).

97. Mr. Justice Jackson observed that the clause "is relatively a neglected one in legal literature .... [It is] both iniportant and obscure to the [legal] profession." Jackson, Full Faith and Credit, 45 Colum. L. Rev. 1, 3 (1945).

98. "Full faith and credit shall be given in each of these States to the records, acts and judicial proceedings of the courts and magistrates of every other state." ARTICLES OF CONFEDERATION OF 1781, art. IV (last paragraph).

99. E.g., 5 Acts and Resolves of the Province of the Massachusetts Bay, c. 16, $\$ 1$ (1774), discussed in Bissell v. Briggs, 9 Mass. *462, *465 (1813): "By this statute, judgments rendered in the courts of the neighboring colonies could not be here [in Massachusetts] impeached, provided the courts rendering those judgments liad competent jurisdiction." [The case incorrectly cites the statute as 14 Geo. 3, c. 2 (Mass. Bay province). Id. at *65.] For a thorough exposition of these precursors to the full faith and credit clause of the Articles of Confederation, see Nadelmann, 
Full Faith and Credit shall be given in each State to the public Acts, Records, and judicial Proceedings of every other State. And the Congress may by general Laws prescribe the Manner in which such Acts, Records and Proceedings shall be proved, and the Effect thereof. 100

Under the clause, a judgment rendered by a state court exercising appropriate jurisdiction ${ }^{101}$ is entitled to the same effect in an enforcement state as it has in the state of rendition. ${ }^{102}$ Thus, the most obvious function performed by the full faith and credit clause and its predecessors

Full Faith and Credit to Judgments and Public Acts, 56 MicH. L. Rev. 33, 36-40 (1957); Costigan, The History of the Adoption of Section $I$ of Article IV of the United States Constitution and a Consideration of the Effect on Judgments of that Section and of Federal Legislation, 4 ColuM. L. Rev. 470, 470-71 (1904).

100. U.S. CoNST. art. IV, $\S 1$.

101. The jurisdictional prerequisite for full faith and credit has never been seriously questioned. Radin, The Authenticated Full Faith and Credit Clause, 39 IrL. L. REv. 1, 21-22 (1944); Reese \& Johnson, The Scope of Full Faith and Credit to Judgments, 49 Colum. L. Rev. 153, 155, 166 (1949). This may be explained in part by the inclusion of a jurisdictional prerequisite in predccessor statutes such as that of the Massachusetts Bay province. See note 99 supra. Although article IV of the Articles of Confederation contains no direct reference to jurisdictional requirements, courts refused to enforce judgments because the rendering courts were without jurisdiction as early as 1786. Kibbe v. Kibbe, Kirby's Rep. (Conn.) 119 (1786). See cases collected in Rheinstein, supra note 1 , at $782 \mathrm{n.23}$. It was not until 1850 , however, that the Supreine Court heard a case under the Constitution's full faith and credit clause and held that the jurisdiction of the rendering court remained subject to reexamination by the forum where enforcement was sought. D'Arcy v. Ketchum, 52 U.S. (11 How.) 165, $175-76$ (1850).

102. The debate as to whether the first section of the clause needed congressional action before becoming effective was mooted on this point in 1790 when Congress provided that "the said records and judicial proceedings ... shall have such faith and credit given to them in every court within the United States as they have by law or usage in the courts of the State from whence the said records are or shall be taken." Act of May 26, 1790, ch. 11, 1 Stat. 122, as amended, 28 U.S.C. $\$ 1738$ (1970). In 1948 the word "acts" was inserted before "records and proceedings" in order to conform the language of the act to that of the Constitution. Act of June 25, 1948, ch. $646, \$ 1,62$ Stat. 947, amending 28 U.S.C. $\$ 1738$ (1948).

Justice Story first took one side of the issue, then the other. In Mills v. Duryee, 11 U.S. (7 Cranch) 481, 485 (1813), he rehed on the congressional act rather than the clause itself in declaring for the majority, "And we can perceive no rational interpretation of the act of congress, unless it declares a judgment conclusive, when a court of the particular State where it is rendered would pronounce the same decision." Later, he took the view that the constitutional provision was self-executing:

Does it import no more than, that the same faith and credit are to be given to them, which, by the comity of nations, is ordinarily conceded to all foreign judgments? Or is it intended to give them a more conclusive efficiency, approaching to, if not identical with, that of domestic judgments; so that, if the jurisdiction of the court be established, the judgment shall be conclusive, as to the merits? The latter seems to be the true object of the clause; and, indeed, it seems difficult to assign any other adequate motive for the insertion of the clause, both in the confederation and in the constitution.

J. Story, Commentaries on the Constitution of the United States $\$ 1303$ (1833). 
was to displace, as between the states, the limited prima facie effect accorded foreign judgments under the rules of comity. ${ }^{103}$

In fact, given the context of jurisdictional rules that were essentially territorial in nature, ${ }^{104}$ article IV's full faith and credit clause together with its privileges and immunities clause ${ }^{105}$ created a system with built-in protections far more effective than those provided by comity. ${ }^{108}$ For, while full faith and credit required that a state enforce final judgments rendered by sister states, the privileges and immunities clause required that each state treat citizens and noncitizens alike. Apphication of offensive substantive laws was, therefore, unlikely when citizens were involved in litigation outside their home state. ${ }^{107}$ Such hitigation was, however, infrequent, and the impact of these clauses was correspondingly himited.

History has altered the contours of the doctrines and practices underlying this interdependence, thereby introducing the stresses that currently beset the full faith and credit clause. Perhaps the most serious stress results from vitiation of the privileges and inmunities clause. While citizenship apparently remains an impermissible basis for differential treatment, ${ }^{108}$ residence has taken its place in areas where reasonable distimctions can be made. ${ }^{109}$ Even this reasonableness test,

103. 1 W. CRosskex, Politics aNd the Constitution 551-53 (1953); Costigan, supra note 99, at 470-71. But see Nadelmann, supra note 99, at 49-50. Probably the most persuasive evidence that this was the intention is found in the comment made by James Wilson at the Constitutional Convention on September 3, 1787, as discussion centered on the use of subsequently adopted language that would make this greater effect mandatory: "[Otherwise] the provision would amount to nothing more than what now takes place among all Independent Nations." J. MAdison, Notes of Debates IN THE Federal Convention of 1787, at 570 (Ohio U. Press 1966).

104. The exact contours of jurisdictional practices prior to Pennoyer v. Neff have been the topic of scholarly debate. Compare Ehrenzweig, The Transient Rule of Personal Jurisdiction, 65 YALE L.J. 289 (1956) with Levy, Mesne Process in Personal Actions at Common Law and the Power Doctrine, 78 Y ALE L.J. 52 (1968).

105. "The Citizens of each State shall be entitled to all Privileges and Immunities of Citizens in the several States." U.S. CoNST. art. IV, $\S 2$.

106. The postulate that these two clauses were formulated as closely relatcd aspects of a single system is supported by their proximity in article IV of the Constitution. Indeed, they were considered as a unit by the Constitutional Convention, probably due to their mutual inclusion in article IV of the Articles of Confederation. The history is recounted in Nadelmann, supra note 99, at 34-36.

107. See Nadelmann, supra note 99, at 51-52, diseussing Millar v. Hall, 1 U.S. (1 Dall.) 229 (1788).

108. For a contrary argument, see note 109 infra and sources cited therein. The fourteenth amendment reads, "[N]or shall any State . . . deny to any person within its jurisdiction the equal protection of the laws." U.S. CoNsT. amend. XIV, $\$ 1$ (einphasis added).

109. For a histing of various rights and privileges that have been held not within the protection of the privileges and inmunities clause of article IV, and an argument that the Court does not mean what it says in cases where residence appears to permit the by-passing of the privileges and immunities clause, see Currie \& Schreter, Uncon- 
however, is imposed by the equal protection clause of the fourteenth amendment, not by the thoroughly finessed privileges and iminunities clause. ${ }^{110}$ In fact, the role of the privileges and immunities clause in protecting forum citizens from the application of discriminatory laws in out-of-state litigation is totally undermined when the choice of law turns on the location of the parties' residences. ${ }^{111}$ Full faith and credit to these judgments may well offend forum sensibilities.

At the same time, widened opportunities for forum selection with choice of law ramifications and imcreased interstate activity produce more and more sister-state judgments for enforcement against forum residents. ${ }^{112}$ It should therefore come as no surprise that controls have been imposed, though crudely, via available doctrine, which provides that full faith and credit need not be given when the rendering court is without jurisdiction. ${ }^{113}$ For example, we have seen that cloice of law restraints are imposed through maintenance of an in rem fiction in divorce jurisdiction. ${ }^{114}$ Similarly, judicial discomfort with the full faith and credit ramifications of finality in child custody cases was undoubtedly at the base of an implication in May $v$. Anderson ${ }^{115}$ that no jurisdictional base exists that can support a final custody decree. ${ }^{118}$

stitutional Discrimination in the Conflict of Laws, 69 YALE L.J. 1323, 1341-49 (1960), reprinted in B. CurRIE, Selected EsSAYS on THE CONFLICT of LAws 445, 465-75 (1963).

110. For a contrary view, see note 109 supra and sources cited therein.

111. See, e.g., Tooker v. Lopez, 24 N.Y.2d 569, 249 N.E.2d 394, 301 N.Y.S.2d 519 (1969) and Justice Breitel's dissent, discussing Miss Silk, a Michigan resident who, due to choice of law results that reflect citizenship, might have been unable to recover in New York although New York citizens involved in the same accident were allowed to benefit from an application of New York law. Id. at 592, 249 N.E.2d at 408, 301 N.Y.S.2d at 539 (Breitel, J., dissenting).

112. Horowitz, Toward a Federal Common Law of Choice of Law, 14 U.C.L.A.L. REv. 1191, 1207-08 (1967) ("I should think that expanded bases of jurisdiction of state conrts would make even more desirable the recognition of choice of law as federal in origin").

113. Reese \& Johnson, supra note 101 , at 170 ([L]ack of jurisdiction is to be relied upon whenever possible as a basis for excusing the refusal by one state to respect another's judgment, since this ground is .... wholly consistent with the command of full faith and credit. . . .").

114. See notes 43-49 supra and accompanying text. A skeptic might suggest that the elusive domiciliary intent reqnirement has been retained precisely because it allows even greater latitude for a jurisdictional attack on ex parte divorces. See text following note 59 supra.

115. 345 U.S. 528 (1953).

116. At issue was a father's attempt to utilize an award of child custody under an ex parte Wisconsin divorce decree in habeas corpus proceedings against his former wife in Ohio. Finding that the Ohio court was not obligated to give full faith and credit to the Wisconsin custody decree, the Court noted, "[W]e recognize that a mother's right to custody of her children is a personal right entitled to at least as much protection as her right to aliunony." Id. at 534 (emphasis added).

The drafters of the 10th Tentative Draft of the Second Restatement analyzed the 
When viewed as a part of a structure designed to govern interstate judicial relationships, it seems remarkable that so little consideration has been given to a broad role for the full faith and credit clause in relationship to choice of law. ${ }^{117}$ Perhaps this is because the clause does not appear to have been considered in tandem with the privileges and immunities clause. Even so, a few rationales have been advanced that base constitutional choice of law control exclusively on the full faith and credit clause.

In a persuasive discussion of the meaning of "Records" as used in the clause, ${ }^{118}$ Professor Crosskey argued:

This strangeness in the wording . . . disappears, however, once the fact is known, that the word "Records," in the eighteenth century, was the technically correct designation of what then were regarded as the real "monuments," or "authoritative evidence," of cominon, or customary, law; and, likewise, of the judicially determined meanings of statutes. For, in view of this fact, and the complete lack, at that time, of any American law-reporting, especially of an official kind, it is clear that the word "Records" was a natural word for the Federal Convention to use if they ineant to provide for the "giv[ing of] full Faith and Credit" to state judicial precedents . . . . 110

It is clear that a requirement of full faith and credit to precedents demands guidance as to when sister-state precedents are controlling for

case differently. Citing May v. Anderson, they suggested the availability of an exception if full faith and credit would entail "an improper infringement of the interests of the [enforcement state]." Restatement (SECONd) of Conflict of Laws $\$ 434 \mathrm{c}$ (Tent. Draft No. 10, 1964). This section was criticized sharply. Ehrenzweig, The Interstate Child and Uniform Legislation, 64 Mich. L. REv. 1-4 (1965); Comment, Full Faith and Credit to Judgments, 54 CALIF. L. REv. 282 (1966). The Second Restatement's version of this section no longer contains a reference to May v. Anderson. Restatement (SeCoNd) of Conflict of Laws $\$ 103$ (1971).

117. Most of the attention given the clause in this area has related to the requirement of full faith and credit to "public acts." Viewed alone, this requirement has confused the courts, producing only a door-opening device, not necessarily substantively controlling [Hughes v. Fetter, 341 U.S. 609, 612 n.10 (1951)], or a stand-off where states have directly conflicting statutes [Pacific Employers Ins. Co. v. Industrial Accident Comm'n, 306 U.S. 493 (1939)].

118. 1 W. CrossKeY, supra note 103, at 545-47.

119. Id. at 546. If it appears strange that such a function was lost sight of, the explanation may well be that proffered by Professor Crosskey and Mr. Justice Jackson: at the time the Constitution was adopted, and for approximately the next 50 years, there were only infrequent and minor conflicts problems. 1 W. CROSSKEY, supra note 103, at 555-56; Jackson, supra note 97, at 6 . And, there was the unifying influence provided by belief in the existence of a federal common law, not to be extinguished until Erie R.R. v. Tompkins, 304 U.S. 64 (1938). Indeed, in a preface dated Jan. 1, 1834, Joseph Story could say:

There exists no treatise upon [the conflict of laws] in the English language; and not the slightest effort has been made, except by Mr. Chancellor Kent, to arrange in any general order even the more familiar maxims of the common law in regard to it.

J. Story, CoMmentaries ON THE CONFLICT OF LAWS v (1835). 
litigational purposes. ${ }^{120}$ According to this analysis, while the clause's second sentence grants Congress plenary legislative authority in the field, its first sentence requires conformity to extant conflicts rules- to be enunciated by the Supreme Court in the absence of relevant Congressional action. ${ }^{121}$ Thus, there is a backdrop of federal common law of choice of law against which Congress may legislate. According to Professor Crosskey, this federal common law of conflicts is an extension of the Roman jus gentium-the law for foreigners-as perpetuated in the Law of Nations. ${ }^{122}$ Professor Rheinstein has traced the same historical lineage, finding in the full faith and credit clause a comparable basis for federal judicial enunciation of jurisdictional rules. ${ }^{123}$

Seemingly, a unified doctrine allowing Supreme Court and congressional control of an integrated law of jurisdiction and choice of law could therefore be based upon the heritage of the Law of Nations. Yet, the day seems long past for acceptance of a "brooding omnipresence" of federal common law. ${ }^{124}$ And there appears to be a logical

120. A variety of enforcement methods would be possible. Reese and Johnson seem to have overlooked the possibility of providing for direct appeal alone on issues arising under constitutionally prescribed choice of law rules. Rather, they make the qnestionable assumption that collateral attack would necessarily be available: "[T]here could be no certain end to a controversy with elements in two or more states until the qnestion of what was the proper law to apply had been successively relitigated in each of those states." Reese \& Johnson, supra note 101, at 172. Von Mehren and Trantman take a similar view:

A forum-oriented choice-of-law process coupled with expansive jurisdictional notions would almost inevitably provoke the defense most obviously available to other legal orders, a refusal to recognize the adjudication unless in the eyes of the putative recognizing forum an appropriate choice-of-law rule had been applied.

von Mehren \& Trautman, supra note 35, at 1133. This Comment argues that our legal order permits the same result through confusion of choice of law and jurisdictional issues, followed by objections to the jurisdictional base. See text accompanying notes 103-16 supra.

If choice of law rules are provided for the purpose of allocating functions annong state legal systems where there is conflict, this issue-analogous to that of competencecan be handled adequately through provision for direct appeal. Indeed, only when a forum choice is so imappropriate that it violates due process standards is collateral attack necessary, and this possibility already exists since a judgment void as violative of due process in the state where rendered is not entitled to full faith and credit.

121. 1 W. CrosskeY, supra note 103 , at 552-54.

122. Id. at 549-53, 566-67.

123. Rheinstein, supra note 1 , at $802-12$.

124. See Southern Pac. Co. v. Jensen, 244 U.S. 205, 222 (1917) (Holmes, J., dissenting) ("The common law is not a brooding omnipresence in the sky but the articulate voice of some sovereign or quasi-sovereign that can be identified ...."). Directly to the contrary, von Mehren and Trautman claim that

[e]ven today ... choice of law remains an area in which enlightened jndges think of an omnipresent law, much as one did in the Swift v. Tyson era of the common law .... Although in practice the universally applicable rule may not be followed, nonetheless it is usually pnrportedly observed, and many waters remain untroubled in principle. . . .

A. von Mehren \& D. TRAUTMan, supra note 40, at 1219 (emphasis added). 
fallacy in the suggestion that this Law of Nations, even were it susceptible to identification and elucidation, would be the appropriate tool for controlling relations among states that are not completely sovereignwhose sovereignty, indeed, is significantly limited by the very clause that is now credited with dictating that the Law of Nations should govern. ${ }^{125}$

It is precisely this restriction on complete sovereignty that provides the basis for a second proffered rationale for judicial and congressional choice of law control under the full faith and credit clause-a rationale that presents a philosophy both suited to current needs for a comprehensive doctrine of jurisdiction and choice of law and compatible with the original interdependence of the full faith and credit and privileges and immunities clauses. Professor Baxter points out that the premise of state autonoiny that undergirds federalism "presupposes [as to local problems] that each state will be permitted to effectuate, to the extent consistent with the identical right of every other state, the policies it adopts."128 Current practice provides no certain protection for this right; that consideration that is accorded sister-state policies is given as a matter of grace by courts that employ a balancing-of-interests approach to choice of law questions. ${ }^{127}$ Professor Baxter argues that federalism requires more: an objective arbiter to ensure effective systemwide results. ${ }^{128}$

It has been argued that this reasoning would support a federal common law of choice of law that is not based on any specific constitutional clause, arising instead by implication out of the very nature of federalism. ${ }^{129}$ Yet it is clear that the development of a national conflicts doctrine was not meant to be left exclusively to the common law. The full faith and credit and privileges and immunities clauses, taken together, represent a deliberate attempt to establish basic standards for legislative and judicial interaction among sister states. Although their articula-

125. Professor Crosskey argued that the use of the word "shall" in the full faith and credit clause made rules that are only moral dicta among sovereign nations binding on the states. He did not question the suitability of that law's contents. $1 \mathrm{~W}$. Crossrey, supra note 103, at 549-53. This is undoubtcdly attributable to confidence in the malleability of the common law.

126. Baxter, supra note 96 , at 24 (emphasis added).

127. In practice, von Mehren and Trautman suggest that the job does get done. See note 124 supra. Professors B. Currie and Ehrenzweig have opposed any weighing approach, arguing that the forum should have no recourse other than application of forum law in the case of any conflict. Indeed, Professor Ehrenzweig avoids the unpleasantness of conflict by insisting that a question of nonforum law is never presented unless forum policy dictates its applicability, a point at which no conflict is therefore possible. B. Currie, Notes on Methods and Objectives in the Conflict of Laws, 1959 DUKE L.J. 171, 178; Ehrenzweig, supra note 8, at 346-49.

128. Baxter, supra note 96 , at 23.

129. Horowitz, Toward a Federal Common Law of Choice of Law, 14 U.C.L.A.L. Rev. 1191 (1967). 
tion is perhaps not as lucid as hindsight might deem desirable, these clauses provide a structure that contains all of the elements essential to a federal law of conflicts.

In fact, enforcement of judgments alone embraces all three traditional topics of the conflicts field-choice of law, jurisdiction, and enforcement of foreign judgments. This is so because a judgment can be defined in terms of basic elements: an appropriate forum-party relationship so that adjudication in the forum is not unfairly imconvenient, opportunity for a full and fair hearing, and application of substantive standards that are reasonable-both vis-à-vis the parties and vis-à-vis any state where enforcement may be sought (potentially any state in the union). Analyzed in this fashion, matters that have traditionally been treated under the due process rubric are indeed vital elements of the full faith and credit requirement of article IV. As to those issues of basic convenience and fairness to hitigants, there is no serious incompatability in continued reliance on due process standards. ${ }^{130}$ For, once power is dismissed as a valid interest, an enforcement state has no independent concern beyond ensuring that its citizens receive fair treatment in their individual capacities.

The choice of law element, however, has a dual nature. Not only is there need for fairness to the hitigants. If each state has a legitimate interest in maximizing its policies to the extent that federalism permits, this interest, too, deserves vindication. It is clear that the traditional test, which measures acceptability only as to the parties, provides no gnarantee that relevant nonforum policies will be appeased. Yet in any case with multistate facets, legitimate policy goals of several states may be pertment. Additional standards are therefore imperative.

Because it deals with the full range of conflicts problems, the full faith and credit clause provides an appropriate framework for efforts at synthesizing choice of law and jurisdictional rules. As suggested in the discussion of a potential in personam base for divorce actions, ${ }^{131}$ direct confrontation of choice of law issues will affect jurisdictional standards that are currently subsumed under due process. Although no basic change is needed in the emphasis on fairness to individuals that due process rubrics provide, even this standard is in part a function of interstate judicial procedures that technology and analysis suggest require up-dating. The close interdependence of jurisdictional practices with fairness to both individuals and the federal system can be acknowledged and dealt with most appropriately under the full faith and credit clause.

130. For a qualification on total self-sufficiency for these purposes, see text accompanying note 131 infra.

131. See text accompanying notes 45-61 supra. 


\section{III}

\section{IMPLEMENTATION}

The ultimate test of a new conflicts rationale will be a pragmatic one: does practice vindicate the posited goals? Independent of doctrine, the subject matter (choice of law and jurisdiction ${ }^{132}$ ) and the identity of the rulemaker (whether the courts, Congress, or state legislatures) have impacts.

\section{A. Defining the Issues}

\section{Choice of Law}

Arguing in favor of Supreme Court delineation of choice of law rules, Mr. Justice Jackson suggested that states need not be concerned with a specter of undue federal influence:

The Federal Government stands to gain little at the expense of the states through any application of [a strong federalist influence in this area]. Anything taken froin a state by way of freedom to deny faith and credit to law of others is thereby added to the state by way of a right to exact faith and credit for its own. ${ }^{133}$

Apparently his reference was to value-free (horizontal) choice rules. ${ }^{134}$ If so, a serious flaw underlies the imitial appeal of his reasoning. In theory, a lateral approach follows froin the premise that, because states in a federal system can legitimately differ in their value judgments, the federal function is one of mere coordination (as distinguished from designation of a "better rule") when conflicts occur. In practice, however, coordination also incorporates value judgments. ${ }^{135}$

Lateral choice directives must be viewed as formulas. The theory

132. Although jurisdictional and choice of law rules have interacting practical effects, analytically they are separable considerations.

133. Jackson, supra note 97 , at 33.

134. [T] here is no constitutional policy that one should or should not recover for alienation of affections, or be subject to strict or easy rules of divorce, or that an injured workman should proceed under one compensation system or another or under common law .....

Jackson, supra note 97 , at 28 . But see note 135 infra. rules:

135. Mr. Justice Jackson was aware of the difficulty in postulating value-free

Certainly the personal preferences of the Justices among the conflicting state policies is not a permissible basis of determining which shall prevail in a case. But only a singularly balanced mind could weigh relative state interests in such subject matter [see note 134 supra] except by resort to what are likely to be strong preferences in sociology, economics, governmental theory, and politics. There are no judicial standards of valuation of such imponderables. ... I leave you pretty much at large on this subject .... . But I could suggest no more engaging intellectual enterprise ... than to find the wise answers on constitutional grounds to these questions.

Jackson, supra note 97 , at 28-29. 
is that application of the formula to a given case will solve the equation, and that although New York may be State $X$ under one set of facts, Texas will assume that role under another set. However, due to regional differences, a formula expressed in terms of debtor-creditor relationships, for example, may in practice find New York in a given role most of the time and Texas in another. Thus, in reality, the states will not have equal opportunity for the application of their conflicting policies in litigation between their citizens. Which policies are most frequently vindicated becomes a function of the value judgments embodied in the formula. For instance, suppose that Texas citizens most frequently find themselves in the role of debtor in their relationships witl New York citizens, and that a federal choice of law rule applies the law of the debtor's state. Sucli a formula would apparently incorporate an intended expression of sympathy for the assumed protective interests that the law of the debtor's state would contain, and in this sense is, of course, a rough-hewn "better law" approach.

There is, however, no assurance that Texas law is indeed solicitous of debtors, and even the intended value judgment of the formula may backfire. For example, if Texas is a state with many debtors, the influences brought to bear on the legislative process may in fact produce legislation with a distinct creditor bias. And, as discussed above, it will not all average out over time since the frequency of application of any given state's law will be a function of the financial profile of its citizens. Subtleties of this sort do not foredoom clioice of law efforts. Rather, they suggest that precise analysis and narrowly refined formulas are required..$^{136}$

\section{Jurisdiction}

Precisely the same problems occur in any attempt to allocate judicial functions through assignment of forum. In a country with geographic subdivisions, each maintaining its own legislative and judicial systems, assignment of forum as sucli can only serve to camouflage, not resolve, the current hiatus in conflicts. ${ }^{137}$ Yet it remains true that

136. The identity of the rulemaking body affects both the data and the analytical process basic to rule formulation. See text accompanying notes 144-63 infra.

137. Similar criticism has been leveled at the approach set forth by Professors von Mehren and Trautman. Carrington \& Martin, Substantive Interests and the Jurisdiction of State Courts, 66 Mich. L. REv. 227, 245-46 (1967). However, although stating that "ideally, the choice-of-law question . . . should be of little significance for the jurisdictional problen," von Mehren and Trautman recognize that "[r]ules respecting the assumption of jurisdiction must take the choice-of-law problem into account when choice is impossible either inherently or as a inatter of practice . . ." von Mehren \& Trautman, supra note 35, at 1128-29 (emphasis in original). Professor Ehrenzweig apparently shares these views. Ehrenzweig, supra note 1, at 107 \& n.30. 
although URESA and trial-by-television provide provocative models for future reform, initial improvement will, of necessity, consist primarily of forum allocation with accompanying choice of law provisions.

In addition to the many choice of law issues discussed above, policy agreement will be required on such basics as the issue of party convenience. Once again, out-of-court ramifications reflect on the acceptability of allocative formulas. For example, a jurisdictional scheme that incorporates the defendant's home as the primary place of trial ${ }^{138}$ will, in practice, enhance a plaintiff's motivation for settlement and provide the defendant with a concoinitant bargaining advantage. When individual plaintiffs and defendants are involved, crowded court calendars, a presumption of innocence, basic disinclination for the involvement of public decisionmaking structures in private affairs, or some combination of these factors, may legitimize jurisdictional rules that incorporate a defendant bias. ${ }^{139}$ On the other hand, just the opposite response seems appropriate in a products liability case where the defendant is a large corporation and the plaintiff is a private individual. Giving this plaintiff ready access to the courts and the benefit of any extrajudicial effects of procedural rules may enhance desirable corporate responsiveness to the impact of corporate activities on individuals. ${ }^{140}$

Recognition that the social functions of the judicial system can vary provides a basis for the analysis of this aspect of jurisdictional rules. It is in those areas where judicial decisionmaking serves to implement societal (as distinguished from private) goals that it is most appropriate to provide plaintiffs with practical inducements to utilize the court structure. ${ }^{141}$ Naturally, the degree to which this function is

138. This is the traditional model. Professors von Mehren and Trautman explain its almost universal acceptance in purely domestic situations as based on the theory that "[t]he status quo as between the parties is not to be lightly changed, and the burden is thus on the plaintiff." von Mehren \& Trautman, supra note 35, at 1127 . Professor Sunderland explaimed the model in a somewhat different manner:

In general our laws have somewhat favored defendants as against plaintiffs, on the theory, probably, that since the plaintiff controls the institution of suit he might behave oppressively toward the defendant unless restricted. Accordingly, many statutes require transitory actions to be brought in the county of a defendant's residence, which, of course, generally serves his convenience.

Sunderland, The Provisions Relating to Trial Practice in the New Illinois Civil Practice Act, 1 U. CHI. L. REv. 188, 192 (1933). Certainly, whether or not the plaintiff has objectionable motives, his ability to dictate the timing of the initial step in litigation-to the extent that it exists-places him at some advantage.

139. See note 138 supra.

140. Carrington and Martin identify the moral judgment embodied in the use of long-arm jurisdiction in products liability cases. Carrington \& Martin, supra note 137, at 247.

141. This motivation prompted the generous venue provisions of the Federal Employers' Liability Act, ch. 143, § 2, 36 Stat. 291 (1910), as amended, 45 U.S.C. $\$ 56$ (1970). Griffith, The Vindication of a National Public Policy Under the Fed- 
relevant to the type of litigation and characteristics of the parties involved should affect the content of jurisdictional rules. ${ }^{142}$ Although the factors that must be weighed in fornulating such distinctions have not yet been satisfactorily defined, ${ }^{143}$ it is important to recognize what is at stake.

\section{B. Instrumentalities of Change}

\section{The Supreme Court}

Experience suggests that a need for sophisticated balancing prompts nebulous judicial formulas, leaving inordinate amounts of discretion to the trial judge. ${ }^{144}$ The result, case-by-case discretion based on ill-defimed standards, does not enhance predictability. ${ }^{145}$ Full faith and credit may, therefore, provide doctrinal insight without increasing the likelihood that its potential will actually be fulfilled on the constitutional level. Analytically, the need to search further for appropriate guideines should be neither surprising nor disheartening. The Constitution, after all, functions both conceptually and operationally as a limit-setter. Flexibility is maintained as specific legislation is formulated in response to changing needs, with courts exercising a veto only

eral Employers Liability Act, 18 LAW \& CONTEMP. ProB. 160, 167 (1953). A nonstatutory example of lessened plaintiff burdens is the allowance of attorneys' fees in actions brought under section 14(a) of the Securities Exchange Act of 1934, ch. 404, $\$ 14$ (a), 48 Stat. 895, as amended, 15 U.S.C. $\$ 78 \mathrm{n}$ (a) (1970). Mills v. Electric AutoLite Co., 396 U.S. 375, 389-97 (1970).

142. See Carrington \& Martin, supra note 137, at 247-48; von Mehren \& Trautman, supra note 35 , at $1166-69$.

143. The most useful analytical tool thus far is the new terminology provided by Professors von Mehren and Trautinan. See von Mehren \& Trautman, supra note 35. Yet, any attempt to provide simple formulas is destined to be excessively vague or inappropriate. For example, 64 possible combinations can result, given only two parties and three variables: corporation/individual, localized activity/multistate activity, and equal economic strength/unequal economic strength. Note that these are not mutually exclusive categories. Indced, even these measurement criteria require analysis. As pointed out by Professor Twerski, the fact that a party has engaged in multistate activity, for exainple, may be of varying relevance. Twerski, A Return to Jurisdictional Due Process, 8 DuQuesne L. Rev. 220, 228-33 (1970). For example, if the Ford Motor Company contracts in California with a local car agency, the multistate nature of Ford's activities is clear, as is the essentially localized activity of the dealer. Is the situation altered im any significant manner if the manager of the agency signs the contract in Michigan during a sales convention? Or, if a Californian on vacation in Michigan buys a car at a Ford assembly plant, is Ford a multistate or a local party in relationship to this transaction? Apparently the individual would be a multistate party under the von Mehren-Trautunan approach. Similar difficulties are encountered in attempts to define relevant economic prowess. Even the corporate/individual variable loses any apparent meaning when one party is a sole proprietor and the other is an incorporated individual. And, if a third party is involved in the litigation, the mathematical possibilities imcrease geometrically.

144. See text accompanying notes 9-23 supra.

145. See text following note 149 infra. 
if limits of constitutional permissibility are breached. Given even the frequency of Supreme Court opportunity for decisions in the areas of jurisdiction and choice of law, an attempt to define rules in terms of the limits is destined to be a vague, patchwork endeavor. ${ }^{140}$ Even more serious, a search that is concerned only with hinits forecloses inquiry within the constitutionally circumscribed area for the anticipated product of our constitutional framework: currently appropriate legislation.

\section{Congress}

Due to the extremely complex ramifications of any comprehensive scheme of jurisdiction and choice of law, however, congressional delineation of conflicts rules cannot be anticipated. Indeed, there is reason to hope that Congress will maintain a passive role, for heavyhanded legislation could be disastrous. ${ }^{147}$

\section{Uniform Legislation}

Two important media remain, offering opportunity for comprehensive, yet flexible, legislation. The first is uniform legislation. A series of enactments, dealing with narrowly defined substantive topics -URESA is a good example - can ease the most troubled areas of interstate conflicts law. The difficulties of formulatimg jurisdictional and choice of law provisions that will satisfy several states cannot, of course, be minimized. Indeed, their complexity suggests that state legislation affords the most flexible, and therefore satisfactory, initial approach to the accommodations that are requisite to a coherent scheme. Optimal uniformity and predictability can be achieved only if such legislation is identical in all states. Yet even disunity in the enacted versions of a "uniform" act would be a step in the right direction and preferable to current confusion. ${ }^{148}$ It should be noted that uniform guides are not incompatible with a significant role for judicial discretion. The need

146. Probably the ultimate response has been achieved in the new California jurisdiction statute: "A court of this state may exercise jurisdiction on any basis not inconsistent with the Constitution of this state or of the United States." CAL. CODB Civ. Pro. \& 410.10. (West Supp. 1971).

147. For the same reason, suggested congressional control under the commerce clause [Horowitz, The Commerce Clause as a Limitation on State Choice-of-Law Doctrine, 84 HaRv. L. REv. 806 (1971)] is undesirable.

148. Even complete uniformity in the enacted versions of a model act would not ensure uniform interpretation unless a new category labeled "uniform acts" is added to the current select list of topics subsumed under federal common law, due to their inherent unsuitability for local control. Alternatively, Supreme Court interpretation of uniform acts is presumably possible under the full faith and credit clause: if the Court has the power to enunciate conflicts rules, there is nothing inconsistent in the exercise of that power through the interpretation of extant rules. 
to balance the merits of predictability against the demerits of inflexibility is ever present. Carrington and Martin have suggested that Rule 19 of the Federal Rules of Civil Procedure, which deals with indispensable parties, ${ }^{149}$ provides a model for the exercise of "balanced discretion." Surely formulas can be developed that will explicate the relevant considerations and provide policy directives within fairly closely defined categories. The choice of law and forum aspects of migratory divorce discussed above ${ }^{151}$ are of the necessary specificity. Similarly suitable, for example, are issues in the products hability field, where multistate commercial activity provides extensive opportunities and rewards for forum shopping.

The quest for statutes acceptable to the legislatures of our diverse states may even produce the interstate coordination of efforts that the full faith and credit clause sought to ensure. The fact, lowever, that even given uniform legislation, state courts can, as in Mong, disregard the provisions of that legislation, ${ }^{152}$ leads to consideration of a second means of state-initiated control.

\section{Interstate Compacts}

Interstate compacts ${ }^{153}$ have long served regional needs that require cooperative interstate efforts. ${ }^{154}$ Here lies untapped potential for significant progress in the conflicts field. Because these agreements are reached only when the states involved have hammered out the terms, the

149. [T] he court shall determine whether in equity and good conscience the action should proceed among the parties before it, or should be dismissed, the absent person being thus regarded as indispensable. The factors to be considered by the court include: first, to what extent a judgment rendered in the person's absence might be prejudicial to him or those already parties; second, the extent to which, by protective provisions in the judginent, by the shaping of relief, or other measures, the prejudice can be lessened or avoided; third, whether a judginent rendered in the person's absence will be adequate; fourth, whether the plaintiff will have an adequate remedy if the actiou is disinissed for nonjoinder.

Fed. R. Crv. P. 19(b).

150. Carrington \& Martin, supra note 137, at 236.

151. See notes 41-59 supra and accompanying text.

152. See Pennsylvania ex rel. Dep't of Pub. Assistance v. Mong, 160 Ohio St. 455,117 N.E.2d 32 (1954), discussed in text accompanying notes 71-75 supra.

153. U.S. CoNST. art. I, $\S 10$ : "No State shall, without the Consent of Congress . . enter into any Agreement or Compact with another State . . . ."

154. Use of interstate compacts dates from colonial times. It was not until 1923, however, that the first regional compact was concluded: the Colorado River Coinpact, which provides for allocation of waters among the basin states. Since that date, there has been a sharp increase in the ratification of compacts. The subject matter has ranged froin water pollution to cooperative use of higher education facilities. The Council of State Governments, Interstate Compacts 1783-1956, at 1-3 (1956). 
necessary congressional approval ${ }^{155}$ should be readily secured..$^{150}$ of course, this approach provides less flexibihity than uniform legislation. At the same time, as compared to national directives estabhished by Congress or the Supreme Court under the full faith and credit clause, compacts ensure greater opportunity for local initiative and continuing control. Indeed, they are especially suited to experiments of limited participation or duration.

This form of state-initiated action provides two distinct advantages: first, true legislative uniformity among the participating states; ${ }^{157}$ second, opportunity for Supreme Court review of state court actions that are inconsistent with compact obligations. ${ }^{158}$ Almost 50 years ago Frankfurter and Landis noted:

[In some] fields uniformity of legislation among the several States is ... necessary. Uniformity is being pursued with marked achievement through the National Conference of Commissioners on Uniform State Laws by securing the independent enactment by the individual States of the same measure. In one instance, at least [the Virginia and Kentucky Compact of $1789^{150}$ ], the Compact Clause ha[s] been

155. Consent of Congress may either be specific, i.e., consent to a particular compact between particular states, or it may be general, in the sense that authorization is given in advance to all compacts which subsequently may be made in a certain designated field. The usual procedure is specific consent to particular arrangements.

F. Zimmerman \& M. Wendell, The LaW and Use of Interstate Compacts 25 (1961). See also note 153 supra. Although not all interstate arrangements are deemed subject to the compact clause, the agreements discussed here appear to fall clearly within its scope. See generally Engdahl, Characterization of Interstate Arrangements: When is a compact not a Compact?, 64 MicH. L. REv. 63 1965).

156. "The only clear case [where consent to a compact was refused] was the failure in the thirties of the Connecticut and Merrimack rivers flood control compacts in the face of a threat of Presidential veto." Id. at 24. Details of the ratification process are discussed in F. ZmMmermann \& M. Wendell, The Interstate Compact SINCE 1925, at 85-101 (1951).

157. Where uniformity of law among the states is needed, it is probably desirable to incorporate such laws in interstate compacts. ... . Since controversies arising froun use of state service compacts are, $\dot{m}$ effect, between the states and individual citizens (rather than between the states as legal entities), state courts can usually adjudicate such cases. ... Since cases arising under interstate compacts can be reviewed by the federal courts, the same renedy for different interpretations is available with respect to compact law as with federal law.

W. Barton, Interstate Compacts in the Political Process 160 (1967).

158. Id. Third-party beneficiary theory should grant standing to sue to the private parties litigant who are the intended beneficiaries of the compact. Note, $A R e$ consideration of the Nature of Interstate Compacts, 35 Colum. L. REv. 76, 82 n.37 (1935).

159. The Virginia Act of December 18, 1789, § 7, by which Kentucky was severed, provides:

[A]ll private rights and interests of land within the said district, derived from the laws of Virginia prior to such separation, shall remain valid and secure 
relied upon for uniformity. Attaining this end through compact assures maintenance of uniformity during the life of the compact. ${ }^{160}$

Due process rationale goes to the existence of jurisdiction; where a given choice of law is constitutionally proscribed, adjudication under the impermissible law produces a void judgment subject to collateral attack. ${ }^{161}$ A significant implication of interstate compacts is that they could easily incorporate opportunity for direct appeal on choice of law matters without providing for the collateral attack of judgments not otherwise void. ${ }^{102}$ The possibility of such refinements augers well for interstate compacts as the tool for implementation of a coherent national law of conflicts. ${ }^{163}$

\section{CONCLUSION ${ }^{164}$}

A strange mixture of history, power, and doctrine, current jurisdictional practice contains significant choice of law aspects. In divorce, for example, the relationship of the two fields, although sometimes confused, is apparent. In quasi in rem jurisdiction, on the other hand, the substantive benefits conferred by jurisdictional rules are relatively obscure. Only in the enforcement of support area, where litigants are financially dismclined to indulge in the niceties of forum sliopping, has there been a radical restructuring of jurisdictional and choice of law practice. Soon telecommunications will provide an economically viable alternative to contemporary long-arm jurisdiction. Yet, because choice of law strikes at the heart of interstate sensitivities, it is all too likely that

under the laws of the proposed state, and shall be determined by the laws now existing in this state.

13 Hening, VA. Srar. Ar L. 17, 19. Congressional consent is found in the act admitting Kentucky into the Union. Act of Feb. 4, 1791, 1 Stat. 189.

160. Frankfurter \& Landis, The Compact Clause of the Constitution, 34 Y ALE L.J. 685, 698 (1925).

161. See generally FED. R. Crv. P. 60(b).

162. See note 120 supra.

163. Experience of the Scandinavian countries in lessening choice of law problenis through both uniform substantive legislation and choice of law treaties nay provide a useful model. Common rules of conflict of laws related to marriage, adoption, and guardianship were adopted in all five Scandinavian nations in 1931. Extensive uniform legislation in other areas has resulted from an ongoing series of conventions. L. Orfield, The Growth of Scandinavian Law 302-06 (1953). Relevant Continental experience under the Hague conventions is discussed in Jayme, Die Wiederanwendung der Haager Familienrechtsabkommen von 1902 und 1905, 18 NEUE JURISTISCHE WochENSCHRIFT 13 (1965) and van Hoogstraten, La Codification par Traités en Droit International Privé dans le Cadre de la Conférence de la Haye, in ACADÉmIE DE DROIT INTERNATIONAL, 122 RECUEIL DES COURS 337 (1967-III).

164. "It seems vcry pretty," she said when she had finished it, "but it's rather hard to understand!" (You see she didn't like to confess, even to herself, that she couldn't make it out at all.) "Somehow it seems to fill my head with ideas-only I don't exactly know what they are!"

L. CARroll, supra note 7, at 19. 
technological and economic feasability will predate the development of suitable legal doctrine.

To the extent that doctrine sliapes the questions and policy judgments that are considered in rulemaking, it may be lielpful to structure future analysis on the full faith and credit clause, whicll appears well suited to a dual inquiry: in addition to those questions of fairness to the parties that are the traditional object of due process concern, interstate policy allocation inust be taken into account. Identification of an appropriate doctrine does not, lowever, conclude the discussion since the identity of the rulemaking body also leaves its imprint. Accordingly, this Comment has argued that locally based solutions in the forn of uniforin legislation or interstate coinpacts are best equipped to deal with the coinplexities of interstate conflict resolution. Of these, interstate compacts are preferable because they combine local initiative with enhanced functional uniformity through Supreme Court supervision. What logic lias neglected, science inay provoke.

Carol Bruch Myers"s

* The writer holds the Washington State (Endowed) Fellowship for 1971-72, awarded by the Committee on Fellowships to American Women of the American Association of University Women. 